\title{
Unearthing time-honored examples of nature-based solutions
}

\author{
Daniele La Rosa ${ }^{1} \cdot$ Stephan Pauleit ${ }^{2} \cdot$ Wei-Ning Xiang $^{3}$
}

Accepted: 16 October 2021 / Published online: 12 November 2021

(c) The Author(s), under exclusive licence to Springer Nature Singapore Pte Ltd. 2021

\section{In search of time-honored examples of nature-based solutions}

Since its conceptions by the International Union for Conservation of Nature (IUCN) in 2012 (IUCN 2012, pp.24-25) and by the European Commission (EC) in 2015 (EC 2015, p.24), nature-based solutions (NBS or NbS) have been gaining steady traction in both professional and academic circles, primarily in the European countries (Kotsila et al. 2021, p.252; Nesshöver et al. 2017, p.1216; O'Sullivan et al. 2020, p.2; Pauleit et al. 2017, pp.31-32). For a most recent example, at the 11th International Conference on Innovation in Urban and Regional Planning (INPUT2020), held September 8-12, 2021, at the University of Catania, Italy, "Integrating NBS into urban and regional planning processes and science" was the overarching theme for discussions [see La Rosa and Privitera (2021)]. A latest Google Scholar search, as another example, resulted in 17,100 English publications since 2016 with "nature-based solutions" in their titles, out of which 7150 were published in the first eight months of this year. ${ }^{1}$

Nature-based solutions are human actions and social processes through which people from all walks of life work together to build and/or renovate nature-inspired,

\footnotetext{
1 The search was done by the authors of this essay on September 27, 2021.
}

Wei-Ning Xiang

wxiang@uncc.edu

Daniele La Rosa

dlarosa@darc.unict.it

Stephan Pauleit

pauleit@tum.de

1 University of Catania, Catania, Italy

2 Technical University of Munich, Munich, Germany

3 University of North Carolina at Charlotte, Charlotte, USA ecosystem-based green infrastructures (GIs) that help address the environmental, social, and economic challenges they face and meet their needs for survival, development, and flourishing (EC 2021c; IUCN 2021). ${ }^{2}$ Among all NBS enthusiasms in the past decade, the most prominent is indisputably a batch of high-profile NBS demonstration projects

\footnotetext{
2 This definition resulted from a consolidation of the official IUCN and EC definitions. To use a congruous NBS definition in this essay, we juxtaposed the latest official NBS definitions on IUCN and EC webpages on October 12, 2021 and made two discoveries. First, they are highly comparable, despite some differences identified in their early versions [see Cohen-Shacham et al. (2016, p.5)] remain evident. IUCN (2021) defines NBS as "actions to protect, sustainably manage, and restore natural or modified ecosystems, that address societal challenges effectively and adaptively, simultaneously providing human well-being and biodiversity benefits"; EC (2021c) defines NBS as "(s)olutions that are inspired and supported by nature, which are costeffective, simultaneously provide environmental, social and economic benefits and help build resilience. Such solutions bring more, and more diverse, nature and natural features and processes into cities, landscapes and seascapes, through locally adapted, resource-efficient and systemic interventions." Second, without specifying exactly what the term "solutions" refers to in the organization's official definition, the EC reports we have reviewed (EC 2015, 2016, 2021b) often refer NBS to either human actions or concomitant results or products the actions lead to. For example, the 2015 EC report states (p.24; italics and parentheses by the authors of this essay), "Nature-based solutions ... are actions inspired by, supported by or copied from nature; both using and enhancing existing solutions [as the products the said actions lead or led to] to challenges, as well as exploring more novel solutions [products the action lead to], for example, mimicking how non-human organisms and communities cope with environmental extremes. Nature-based solutions [as products] use the features and complex system processes of nature, such as its ability to store carbon and regulate water flows, in order to achieve desired outcomes, such as reduced disaster risk and an environment that improves human well-being and socially inclusive green growth." Similar confounding statements can be found in other EC reports we used [e.g., EC (2016, p.28); EC (2021b, p.17)]. For clarity, we checked MerriamWebster.com Dictionary and found that the term "solution" refers to "an action or process of solving a problem" (Merriam-Webster 2021a). We then derived the above definition by consolidating the comparable official IUCN (2021) and EC (2021c) definitions with the minor but nontrivial adjustment on the latter. Finally, to help remove the ambiguities over both terms GIs and NBS (Hansen et al. 2021, pp.257-259), we chose to use GIs in the NBS definition. This will be elaborated in footnote 4 of this essay.
} 
Table 1 Key features of an effective NBS project. [adapted from EC (2016, p.28)]

\begin{tabular}{ll}
\hline 1 & The project is inspired and supported by nature and harnesses the properties and functions of natural ecosystems; \\
2 & Its GI products provide ecological, social, cultural, and economic benefits; \\
3 & The project, through its GI products, brings more natural features and processes into cities and communities; \\
4 & Its GI products are locally attuned, resource efficient, multi-purpose, and multi-functional; \\
5 & The project and its GI products stand the test of time \\
\hline
\end{tabular}

in selected cities and regions, primarily in Europe (EC 2015, 2016, 2020, 2021a, b). These projects are funded by the European Commission through the "nature-based solutions and re-naturing cities" initiative in its Horizon 2020 program (EC 2015, pp.5-6; EC 2016; EC 2021a, b), aiming inter alia "to provide best-practice examples that can be replicated globally." [Cohen-Shacham et al. 2019, p.20; EC 2016, p.29, p.31, p.35; O'Sullivan et al. 2020, p.1 (the quote) $]^{3}$ These anticipated best NBS practice examples, according to the European Commission (2015, p.24; 2016, p.28), would showcase effective NBS projects that possess a set of "key features" (EC 2016, p.28; see Table 1). ${ }^{4}$

\footnotetext{
${ }^{3}$ For a list of these projects, see the link in EC (2021a) and "Table 1-2. Summaries of previous and ongoing projects and programmes working on NBS (2007-2022)" (EC 2021b, pp.29-33).

${ }^{4}$ What is EC's definition of green infrastructure? The 2016 EC report (EC 2016, p.31) does not provide a definition but directs readers to a 2013 EC communication entitled Green Infrastructure (GI) - Enhancing Europe's Natural Capital (EC 2013). In this communication, green infrastructure is defined as "a strategically planned network of natural and semi-natural areas with other environmental features designed and managed to deliver a wide range of ecosystem services. It incorporates green spaces (or blue if aquatic ecosystems are concerned) and other physical features in terrestrial (including coastal) and marine areas. On land, GI is present in rural and urban settings." (Ibid., p.3) This GI definition is comparable to an earlier American definition. In August 1999 under the leadership of The Conservation Fund and the US Department of Agriculture Forest Service, a working group of local, state, and federal agencies and NGOs developed the following GI definition: "Green infrastructure is our nation's natural life support system - an interconnected network of waterways, wetlands, woodlands, wildlife habitats, and other natural areas; greenways, parks and other conservation lands; working farms, ranches and forests; and wilderness and other open spaces that support native species, maintain natural ecological processes, sustain air and water resources and contribute to the health and quality of life for America's communities and people." (Benedict and McMahon 2002a, p.6) Later, two working group leaders, Mark Benedict and Edward McMahon, developed it into a more succinct version which has since become "the most cited definition of GI" (Liao 2019, p.67): "an interconnected network of green space that conserves natural ecosystem values and functions and provides associated benefits to human populations" (Benedict and McMahon 2002b, p.12). In this essay, we adopted these broad GI definitions and used GIs as an umbrella term, while acknowledging other more specific yet equally effective definitions [e.g., the definition of urban green infrastructure (UGI) by Hansen et al. (2017, p.3)].
}

Why is it necessary to create such examples through funded projects? The 2016 EC report explains, "Robust EU-wide evidence of the cost-effectiveness and longer-term social, economic, cultural and ecological benefits of these solutions [NBS and their GI products, that is-see footnote 2 of this essay] is currently lacking and this has prevented their wider deployment." (EC 2016, p.28) Still, it is noteworthy that only a year earlier in 2015 did the European Commission showcase a set of practical projects from around the world, including several from the EU countries, as "examples of nature-based solutions" (EC 2015, pp.52-66). Why did these EU examples not make the Commission's "EUwide evidence" list? The projects in these examples and their GI products might not be "robust" enough, one may speculate solely based on their recency-they were either still ongoing or newly completed at the time of 2016 reporting and had yet to stand the test of both time and practice (see key feature 5 in Table 1).

\section{Effective NBS projects and long-standing Gls they yielded}

While the above statement about the lack of "robust EUwide evidence" is still subject to further vindication, there is already a myriad of robust evidence worldwide. These are effective NBS projects and long-standing GI products they led to throughout the world that possess, or even go above and beyond, those key features the European Commission identified in its 2016 report (see Table 1). In fact, building nature-inspired GIs belongs to a broad class of fundamental and arguably primordial social practice Homo sapiens has been involuntarily engaging in throughout thousands of years of co-evolution with nature. This social practice is codified lately as socio-ecological practice (La Rosa 2019; Liao 2019; Steiner 2020; Xiang 2019a).

Socio-ecological practice is an umbrella term referring to "the human action and social process that take place in specific socio-ecological context to bring about a secure, harmonious, and sustainable socio-ecological condition serving human beings' need for survival, development, and flourishing. Socio-ecological practice includes six distinct yet intertwining classes of human action and social 
process-planning, design, construction, restoration, conservation, and management." (Xiang 2019a, p.7).

Throughout the history of socio-ecological practice, human beings have created a great wealth of effective projects of building nature-inspired GIs whose products provide lasting benefits and stand the test of time. By the European Commission's standards (Table 1), these projects today would be qualified for and could therefore be termed, effective NBS projects. Some of them have been documented and archived, but many of them have not. Among those documented are the projects leading to the Dujiangyan (都江 堰) irrigation system in Sichuan, China (256 BC-present) (Needham et al. 1971, p.288; Xiang 2014, pp.65-66); the Fushougou (福寿沟) stormwater management system in Ganzhou (赣州), China (1069-present) (Han 2012); the Red Flag Canal in Henan, China (1969-present) (Chen and Xiang 2020a, b; Li et al. 2021; Xiang 2020a); the Woodlands New Community in Texas, USA (1974-present) (Forman 2002, pp.102-104; Lyle 1999, p.103, p.237; McHarg 1996, pp.256-264; Xiang 2016, pp.56-57; Xiang 2019b, pp.166-167; Yang 2019; Yang and Li 2016; Yang and Li 2019, pp.217-219); afforested woodlands in the Alps that provide multiple ecosystem services (Knott 1991; Mayer and Ott 1991); Škocjanski Zatok Nature Reserve in Koper, Slovenia, that helps mitigate local impacts of sea level rise (Ivajnšič and Kaligarič, 2014; Jurinčič et al. 2011); ancient woodlands and urban parks in many European cities, such as Eilenriede in the heart of Hanover, Germany (Landeshauptstadt Hannover 2016; Oppermann and Thies 2017).

\section{Problem-solving projects versus demonstration projects}

These effective NBS projects are all problem-solving projects with three distinctive characteristics that distinguish them from those EC funded demonstration projects.

First, as problem-solving projects, they are impelled directly by the local needs, not driven by external grants. As such, their ultimate standard of success is whether the problems they are entitled to address are resolved completely or mitigated to the satisfaction of the local people; not if the policy ideas, scientific principles, or proposed management guidelines they are commissioned to demonstrate are efficacious-have the power to produce anticipated effects. ${ }^{5}$

Second, as problem-solving projects, they have no stopping rule and entail recurring operations. Because the real-world problems they aim to address within specific

\footnotetext{
${ }^{5}$ A case in point here is the EC evaluation standards for NBS (demonstration) project performance, including principles, approaches, and indicators [see EC (2021b)].
}

socio-ecological contexts are wicked by nature (Xiang 2019a, p.8), ${ }^{6}$ it is less if ever possible to have a clearly defined and/or collectively agreed set of criteria for measuring and determining project success or even progress; furthermore, implemented solutions often if not always create new, unexpected problems that require additional efforts and continuous reworking. By contrast, the demonstration projects can and almost always have to follow "procrustean strategies" (Schön 1987/2001, p. 192) to avoid the wicked parts of real-world problems (Xiang 2021a, p.83); they thus have clear-cut criteria jointly set by the granters and grantees for measuring and determining success in efficacy demonstration (Churchman 1967, B-141). With well-defined stopping rule, demonstration projects are one-shot deals.

Third, as problem-solving projects, they operate through a trial-and-error process, instead of a planned project lifecycle. The socio-ecological practice of building nature-inspired GIs in these projects is by and large what the British sociologist Stephen Ball and the Lebanese-American essayist Nassim Taleb described a trial-and-error process of bricolage and tinkering. In this process, practitioners-the project doers-proceed with "the zest for bricolage" and "hunger for trial and error" (Taleb 2012, p.226), barely following general principles or step-by-step guidelines even when they are readily available (Davoudi 2006, p.22). Using "fast and frugal heuristics" in "an adaptive toolbox" (Gigerenzer 2008; Gigerenzer \& Brighton 2009, p.120, p.134), they borrow and copy bits and pieces of ideas from elsewhere, draw upon and amend locally tried and tested approaches, cannibalize known theories, techniques, and technologies (Ball 1998, p.126). ${ }^{7}$ By contrast, commonplace in the demonstration projects is a systematic process, championed by many academic researchers (e.g., Albert et al. 2021; Cohen-Shacham et al. 2019; Woodruff \& BenDor 2016, among many others), of recontextualizing and implementing general principles or policy/management guidelines (e.g., EC 2021b).

\footnotetext{
${ }^{6}$ For a summary on "wicked problems and tame problems", see Xiang (2021a, pp.76-77); for the origin of the conceptions, see Churchman (1967) and Skaburskis (2008); for the seminal articulation of wicked problems, see Rittel and Webber (1973); for a recent literature review, see Termeer et al. (2019).

7 This is even true for state-initiated problem-solving projects. A case in point is the afforestation on slopes in the European Alps (Bebi et al. 2017). Since the early nineteenth century, it has been and remains to be a constant trial-and-error process of bricolage and tinkering.
} 


\section{Time-honored examples of nature-based solutions}

Because of these distinctive characteristics, these effective NBS projects along with their long-standing GI products set a type of NBS examples that on the one hand, meets, or even goes above and beyond, the EC standards (Table 1); but on the other hand, is different from the best NBS practice examples the EC funded projects aim to produce (EC examples henceforth for brevity). They are time-honored NBS examples (henceforth) of real-world problem-solving created inadvertently by generations of practitioners through a trial-and-error process of bricolage and tinkering. Here, the adjective time-honored means literally being "honored because of age or long usage" (Merriam-Webster 2021b).

Specifically,

(1) These time-honored NBS examples are concrete instances of effective real-world problem-solving, which may or may not be imitated but certainly cannot be "replicated globally" as has been anticipated for the EC examples [O'Sullivan et al. 2020, p.1 (the quote)];

(2) Their exemplary status is a recognition rather than an anticipation - an unexpected byproduct of problemsolving activities performed only to the satisfaction of local and/or regional communities, not an anticipated deliverable to meet a priori standards of success set by the granters and grantees of demonstration projects. As such, these time-honored NBS examples, however imperfect they may be, serve as more realistic and compelling inspirations for practitioners and the general public;

(3) They are results of continuous acts of bricolage and tinkering performed by generations of practitioners and/ or scholar practitioners with use-inspired approaches to research, not products of one-shot demonstration projects done by academic researchers and/or knowledge brokers with curiosity-inspired approaches. Therefore, these time-honored NBS examples and the underlying approaches resonate more closely with the ways realworld practitioners do their jobs. ${ }^{8}$

With these characteristics, the time-honored NBS examples constitute a unique fountainhead of inspiration and ecophronesis [i.e., ecological practical wisdom; see Austin

\footnotetext{
8 [1] For a recent account on approaches to research in socio-ecological practice, including use-inspired approaches and curiosity-inspired approaches, see Xiang (2021a). [2] scholar-practitioners are scholars who are committed to generating new knowledge that is useful to practitioners and enlightening to fellow scholars (Xiang 2019a, p.7; Xiang 2019b, p.165; Xiang 2021a, p.79). Socio-ecological scholarpractitioners is a derivative and coined by Graef et al. (2021, p.111).
}

(2018); Xiang (2016)] and a valuable source of instructive lessons that complement the examples the EC funded demonstration projects aim to create.

\section{Digging up time-honored examples of nature-based solutions}

Unfortunately, a great many time-honored NBS examples throughout the human history remain the best kept secrets and mostly undocumented. Examples that are documented, on the other hand, like those listed in Sect. 2 of this essay, are usually known only by people in a small geography or among scholars of a particular field (e.g., cultural anthropology; regional geography; history of science and technology; histories of architecture, landscape architecture, urban and regional planning; sinology; traditional ecological knowledge; ecological wisdom). ${ }^{9}$ Consequently, time-honored NBS examples as a whole are not in the public knowledge domain. As a historical heritage with intrinsic values, they are much underappreciated; as buried resources of inspiration and ecophronesis, they await our exploitation to benefit the contemporary socio-ecological practice

As such, we hereby advocate with great enthusiasm the unearthing and documenting of time-honored NBS examples. We invite practitioner and scholar colleagues from around the world

(1) To actively dig into histories of socio-ecological practice for time-honored NBS examples, systematically document the human actions and social processes these examples entail, critically examine both the acts of bricolage and tinkering practitioners took and the concomitant consequences, closely investigate the ways practitioners coped with the wicked parts of real-world problems, and showcase the long-standing GI products as tangible manifestations of human NBS endeavors;

(2) To explore and/or illustrate ways through which these time-honored NBS examples, once unearthed and documented, can be made more useful-relevant, actionable, and efficacious (Xiang 2019c, p.1)—to the

\footnotetext{
$\overline{9}$ For example, "In the classic Chinese history book Shiji (《史记》, Records of the Grand Historian), historian Sima Qian ( 司马迁, ca. 145BC-86BC) [Sima, 94BC/1959] documents the successful operation of the Dujiangyan irrigation system a century after its construction, and praises the many benefits delivered to people in the region (Peng 2008, pp. 540-541). British historian and sinologist Joseph Needham writes, upon visiting the Dujiangyan irrigation system in 1943 (Cao et al. 2010, p. 5), that ' ... [The Dujiangyan irrigation system is] one of the greatest of Chinese engineering operations which, now 2200 years old, is still in use and makes the deepest impression on all who visit it today' (Needham et al. 1971, p.288)." (Xiang 2014, p.65).
} 
contemporary socio-ecological practitioners and socioecological scholar-practitioners in NBS practice and research. This task necessarily requires the prudent use of a holistic socio-ecological approach, as advocated by many authors (e.g., Bayulken et al. 2021; Curran and Hamilton 2020; Janzen and Fischborn 2016; Kotsila et al. 2021; La Rosa and Pappalardo 2020; Shi 2020), through which societal issues pertaining to equity and justice are taken into due consideration in NBS practice and research;

(3) To showcase concrete instances in which a time-honored NBS example was made useful to, and actually used by, real-world practitioners in their socio-ecological practice of building nature-inspired GIs;

(4) To develop articles that present these findings precisely "in small words" (Xiang 2020b) and share through Socio-Ecological Practice Research (SEPR), the home journal of Ecopracticology - the study of socioecological practice (Xiang 2019a, p.12), so that they are permanently archived in what we hope to build the international depository of time-honored NBS examples.

"There is nothing as inspirational as a good example." (Xiang 2020b, p.126) In the very spirit underlying this aphorism, we admire EC's ambition to create effective NBS examples and applaud the endeavor toward this end through the demonstration projects; at the same time, as outlined above, we take on an equally important and challenging task and cordially invite practitioners and scholar-practitioners from all pertinent professional and academic fields to join us in this worthy adventure.

Acknowledgements The original idea of this guest editorial emerged at the $11^{\text {th }}$ International Conference on Innovation in Urban and Regional Planning (INPUT2020), held September 8-12, 2021, at the University of Catania, Italy. The conference was organized by LAPTA, a research laboratory in the Department of Civil Engineering and Architecture. Among the main inspirations were the central theme of the conference, "Integrating NBS into urban and regional planning processes and science", the two keynote speeches (Pauleit 2021; Xiang 2021b), and in-depth discussions at the question and answer sessions.

\section{References}

Albert C, Brillinger M, Guerrero P et al (2021) Planning nature-based solutions: principles, steps, and insights. Ambio 50:1446-1461. https://doi.org/10.1007/s13280-020-01365-1

Austin H (2018) The virtue of Ecophronesis: an ecological adaptation of practical wisdom. Heythrop J 59(6):1009-1021

Ball SJ (1998) Big policies/small world: an introduction to international perspectives in education policy. Comp Educ 34(2):119-130

Bayulken B, Huisingh D, Fisher PM (2021) How are nature based solutions helping in the greening of cities in the context of crises such as climate change and pandemics? A comprehensive review. J Clean Prod 288:125569
Bebi P, Seidl R, Motta R et al (2017) Changes of forest cover and disturbance regimes in the mountain forests of the Alps. For Ecol Manag 388:43-56

Benedict MA, McMahon ET (2002a) Green infrastructure: smart conservation for the 21st century. Sprawl Watch Clearinghouse Monograph Series, Sprawl Watch Clearinghouse \& The Conservation Fund, Washington, D.C. http://www.sprawlwatch.org/green infrastructure.pdf (accessed October 9, 2021)

Benedict MA, McMahon ET (2002b) Green infrastructure: smart conservation for the 21st century. Renew Resour J 20(3):12-17

Cao SY, Liu XN, Er HA (2010) Dujiangyan irrigation system-a world cultural heritage corresponding to concepts of modern hydraulic science. J Hydro-Environ 4(1):3-13

Chen Y, Xiang W-N (2020a) Why was Tao Lujia so willing and swift to greenlight the Red Flag Canal Project in 1960? The instance and his reflections. Socio Ecol Pract Res 2(4):329-335. https:// doi.org/10.1007/s42532-020-00060-5

Chen Y, Xiang W-N (2020b) Why was Tao Lujia so willing and swift to greenlight the Red Flag Canal Project in 1960? New insights via a lens of compassion practice. Socio Ecol Pract Res 2(4):337-346. https://doi.org/10.1007/s42532-020-00061-4

Churchman CW (1967) Wicked problems. Manag Sci 14(4):B141-B142

Cohen-Shacham E, Maginnis S, Smith M et al (2016) 1.2 Defining NbS. In: Cohen-Shacham E, Walters G, Janzen C, Maginnis S (eds) (2016) Nature-based Solutions to address global societal challenges. Gland, Switzerland: IUCN. xiii + 97pp. 5-7. https:// portals.iucn.org/library/sites/library/files/documents/2016-036. pdf . Accessed 3 Sept 2021

Cohen-Shacham E, Andrade A, Dalton J, et al (2019) Core principles for successfully implementing and upscaling nature-based solutions. Environmental Science and Policy 98:20-29. https://www. sciencedirect.com/science/article/pii/S1462901118306671

Curran W, Hamilton T (2020) Nature-based solutions in hiding: goslings and greening in the still-industrial city. Socio Ecol Pract Res 2(4):321-327. https://doi.org/10.1007/s42532-020-00064-1

Davoudi S (2006) Evidence-based planning: rhetoric and reality. disP-The Planning Review, 42(165):14-24, https://doi.org/10. 1080/02513625.2006.10556951

EC (The European Commission) (2013) Green infrastructure (GI) - enhancing Europe's natural capital. European Commission, Brussels, Belgium. https://ec.europa.eu/environment/nature/ ecosystems/docs/green_infrastructures/1_EN_ACT_part1_v5. pdf (Accessed October 9, 2021)

EC (The European Commission) (2015) Towards an EU research and innovation policy agenda for nature - based solutions and renaturing cities. Final Report of the Horizon 2020 Expert Group on Nature-based Solutions and Re - Naturing Cities. European Commission, Brussels, Belgium. file:///C:/Users/yingc/Downloads/ ki0215162enn_002_10195.pdf (Accessed September 3, 2021)

EC (The European Commission) (2016) Horizon2020 Work Programme 2016-2017: 12. Climate action, environment, resource efficiency and raw materials. European Commission, Brussels, Belgium. https://ec.europa.eu/research/participants/data/ref/ h2020/wp/2016_2017/main/h2020-wp1617-climate_en.pdf (Accessed September 3, 2021)

EC (The European Commission) (2020) Biodiversity and nature-based solutions: analysis of EU-funded projects. European Commission, Brussels, Belgium. file:///C:/Users/yingc/Downloads/NBS_BD_ EUProjects_2020.pdf (accessed October 9, 2021)

EC (The European Commission) (2021a) CORDIS: EU research results. https://cordis.europa.eu/search?q=contenttype $\% 3 \mathrm{D} \%$ 27 project $\% 27 \% 20$ AND $\% 20$ programme $\% 2$ Fcode $\% 3 \mathrm{D} \% 27 \mathrm{H} 20$ 20-EU.3.5.2.1.\%27\&p=1\&num $=10 \& \mathrm{srt}=/ \mathrm{project} / \mathrm{contentUpd}$ ateDate:decreasing (accessed September 29, 2021) 
EC (The European Commission) (2021b) Evaluating the impact of nature-based solutions: a handbook for practitioners. European Commission, Brussels, Belgium. file:///C:/Users/yingc/Downloads/KI0420586ENN.en.pdf (accessed October 9, 2021)

EC (The European Commission) (2021c) Nature-based solutions. https://ec.europa.eu/info/research-and-innovation/research-area/ environment/nature-based-solutions_en (accessed October 12, 2021)

Forman RTT (2002) The missing catalyst: design and planning with ecological roots. In: Johnson BR, Hill K (eds) Ecology and design: frameworks for learning. Island Press, Washington, DC, pp 85-109

Gigerenzer G (2008) Fast and frugal heuristics. In: Gigerenzer G (ed) Rationality for mortals: how people cope with uncertainty. Oxford University Press, New York, pp 20-45

Gigerenzer G, Brighton H (2009) Homo heuristicus: why biased minds make better inferences. Top Cog Sci 1:107-143

Graef DJ, Motzer N, Kramer JG (2021) The value of facilitation in interdisciplinary socio-environmental team research. Socio Ecol Pract Res 3(2):109-113. https://doi.org/10.1007/ s42532-021-00082-7

Han Z (2012) Fushougou, an urban stormwater management system built in the Song Dynasty, China. Chinese Social Sciences Today, 243. [韩振飞 (2012) 宋代排水工程“福寿沟”的营造。《中国社 会科学报》, 243期]

Hannover L (2016) Landeshauptstadt Hannover, Fachbereich Umwelt und Stadtgrün, Hanover, 45 p., https://www.hannover.de/KulturFreizeit/Naherholung/Natur-entdecken/Wälder/Die-Eilenriede (accessed October 11, 2021)

Hansen R, van Lierop M, Rolf W et al (2021) Using green infrastructure to stimulate discourse with and for planning practice: experiences with fuzzy concepts from a pan-European, a national and a local perspective. Socio Ecol Pract Res 3(3):257-280. https://doi. org/10.1007/s42532-021-00087-2

Hansen R, Rolf W, Pauleit S, et al (2017) Urban green infrastructure. A foundation of attractive and sustainable cities. Pointers for municipal practice. Federal Agency for Nature Conservation (BfN), Bonn, Germany

IUCN (The International Union for Conservation of Nature) (2012) The IUCN Programme 2013-2016. IUCN, Gland, Switzerland. https://portals.iucn.org/library/sites/library/files/documents/WCC5th-003.pdf (accessed September 19, 2021)

IUCN (The International Union for Conservation of Nature) (2021) Nature-based solutions. https://www.iucn.org/commissions/ commission-ecosystem-management/our-work/nature-based-solut ions (accessed October 12, 2021)

Ivajnšič D, Kaligarič M (2014) How to preserve coastal wetlands, threatened by climate change-driven rises in sea level. Environ Manag 54:671-684

Janzen C, Fischborn M (2016) 4. Lessons learned from the case studies. In: Cohen-Shacham E, Walters G, Janzen C, Maginnis S (eds) (2016) Nature-based Solutions to address global societal challenges. Gland, Switzerland: IUCN. xiii + 97pp. 25-26. https:// portals.iucn.org/library/sites/library/files/documents/2016-036. pdf . Accessed 3 Sept 2021

Jurinčič I, Balažič G, Sinkovič LJ (2011) Škocjanski Zatok Nature Reserve as opportunity for development of ecological tourism. In: Perić J (ed) Sustainable tourism: socio-cultural, environmental and economics impact, Volume 1 of Tourism in South East Europe, ISSN 1848-4050, 147-158. University of Rijeka, Faculty of Tourism and Hospitality Management, Rijeka, Croatia

Knott H (1991) Geschichte der Salinenwälder von Berchtesgaden. Forschungsberichte der Nationalparkverwaltung Berchtesgaden 12, Nationalparkverwaltung Berchtesgaden, p 55

Kotsila P, Anguelovski I, Baro F et al (2021) Nature-based solutions as discursive tools and contested practices in urban nature's neoliberalisation processes. Environ Planning. e, Nat Space 4(2):252-274

La Rosa D (2019) Why is the inclusion of the ecosystem services concept in urban planning so limited? A knowledge implementation and impact analysis of the Italian urban plans. Socio Ecol Pract Res 1(2):83-91. https://doi.org/10.1007/s42532-019-00016-4

La Rosa D, Pappalardo V (2020) Planning for spatial equity-A performance based approach for sustainable urban drainage systems. Sustain Cities Soc 53:101885

La Rosa D, Privitera R (Eds.) (2021) Innovation in urban and regional planning. In: Proceedings of the 11th INPUT Conference - Volume 1. Springer, Switzerland

Li Y, Gao W, Xiang W-N (2021) "The trouble", its maker, and Yang Gui's confidence in "taming the troublemaker" with a 1962 bilateral agreement. Socio Ecol Pract Res. https://doi.org/10.1007/ s42532-021-00095-2

Liao KH (2019) The socio-ecological practice of building blue-green infrastructure in high-density cities: what does the $\mathrm{ABC}$ waters program in Singapore tell us? Socio Ecol Pract Res 1(1):67-81. https://doi.org/10.1007/s42532-019-00009-3

Lyle JT (1999) Design for human ecosystems: landscape, land use, and natural resources. Island Press, Washington, DC

Mayer H, Ott E (1991) Gebirgswaldbau Schutzwaldpflege: ein waldbaulicher Beitrag zur Landschaftsokologie und zum Umweltschutz, 2nd edn. Fischer Verlag, Stuttgart

McHarg IL (1996) A quest for life: an autobiography. Wiley, New York

Merriam-Webster (2021a) Solution. In: Merriam-Webster.com dictionary. Retrieved October 13, 2021, from https://www.merri am-webster.com/dictionary/solution

Merriam-Webster (2021b) Time-honored. In: Merriam-Webster.com dictionary. Retrieved October 13, 2021, from https://www.merri am-webster.com/dictionary/time-honored

Needham J, Wang L, Lu G-D (1971) Science and civilization in China. Volume4: physics and physical technology, Part III: civil engineering and nautics. Cambridge University Press, Cambridge, UK

Nesshöver C, Assmuth T, Irvine KN et al (2017) The science, policy and practice of nature-based solutions: an interdisciplinary perspective. Sci Total Environ 579:1215-1227

O’Sullivan F, Mell I, Clement S (2020) Novel solutions or rebranded approaches: evaluating the use of Nature-Based Solutions (NBS) in Europe. Frontiers in Sustainable Cities, 2:572527. https://www. frontiersin.org/articles/https://doi.org/10.3389/frsc.2020.572527/ full

Oppermann B, Thies M (2017) Freiraum Urbaner Wald Die Eilenriede in Hannover. Ein Diskussionspapier. University of Hanover, Hanover, https://www.freiraum.uni-hannover.de/fileadmin/freiraum/ FPPK/FPPK_Forschung/2017_Diskussionspapier_Eilenriede_ opp_th.pdf (accessed October 11, 2021)

Pauleit S, Zölch T, Hansen R et al (2017) Nature-based solutions and climate change-four shades of green. In: Kabisch N, Korn H, Stadler J, Bonn A (eds) Nature-based solutions to climate change adaptation in urban areas: linkages between science, policy and practice, 29-49. Springer, Cham, Switzerland. https://doi.org/10. 1007/978-3-319-56091-5_3

Pauleit S (2021) Urban green infrastructure for climate resilient cities - building actions from evidence. A keynote speech at the 11th International Conference on Innovation in Urban and Regional Planning (INPUT 2020), September 9, 2021. The University of Catania, Italy. http://www.input2020.unict.it/

Peng B (2008) Dujiangyan irrigation system: a case of East Asia local knowledge with universal significance. Front Hist China 3(4):533-550

Rittel HWJ, Webber MM (1973) Dilemmas in a general theory of planning. Policy Sci 4:155-169 
Schön D (1987/2001) The crisis of professional knowledge and the pursuit of an epistemology of practice. In: Raven J (ed) Competence in the learning society, 183-207. Peter Lang: NewYork

Shi L (2020) Beyond flood risk reduction: how can green infrastructure advance both social justice and regional impact? Socio Ecol Pract Res 2(4):311-320. https://doi.org/10.1007/s42532-020-00065-0

Sima Q (94BC/1959) Shiji (Records of the Grand Historian). Zhonghua Press, Beijing [司马迁 (1959)《史记》。中华出版社, 北京]

Skaburskis A (2008) The origin of "wicked problems." Plan Theory Pract 9(2):277-280

Steiner F (2020) Landscape governance: the prospects for the SITES rating system. Socio Ecol Pract Res 2(4):301-310. https://doi.org/ 10.1007/s42532-020-00068-x

Taleb NN (2012) Antifragile: things that gain from disorder. Random House, New York, USA

Termeer CJAM, Dewulf A, Biesbroek R (2019) A critical assessment of the wicked problem concept: relevance and usefulness for policy science and practice. Policy Soc. https://doi.org/10.1080/ 14494035.2019.1617971

Woodruff S, BenDor TK (2016) Ecosystem services in urban planning: comparative paradigms and guidelines for high quality plans. Landsc Urban Plan 152:90-100

Xiang W-N (2014) Doing real and permanent good in landscape and urban planning: ecological wisdom for urban sustainability. Landsc Urban Plan 121:65-69

Xiang W-N (2016) Ecophronesis: the ecological practical wisdom for and from ecological practice. Landsc Urban Plan 155:53-60

Xiang W-N (2019a) Ecopracticology: the study of socio-ecological practice. Socio Ecol Pract Res 1(1):7-14. https://doi.org/10.1007/ s42532-019-00006-6

Xiang W-N (2019b) History voted many times in Ian McHarg's favor. Socio Ecol Pract Res 1(2):165-169. https://doi.org/10.1007/ s42532-019-00013-7

Xiang W-N (2019c) Socio-ecological practice research (SEPR): what does the journal have to offer? Socio Ecol Pract Res 1(1):1-5. https://doi.org/10.1007/s42532-018-0001-y

Xiang W-N (2020a) The red flag canal: a socio-ecological practice miracle from serendipity, through impossibility, to reality. Socio Ecol Pract Res 2(1):105-110. https://doi.org/10.1007/ s42532-019-00037-z

Xiang W-N (2020b) From good practice for good practice we theorize; in small words for big circles we write. Socio Ecol Pract Res 2(1):121-128. https://doi.org/10.1007/s42532-020-00040-9

Xiang W-N (2021a) Seven approaches to research in socio-ecological practice \& five insights from the RWC-Schön-Stokes model. Socio Ecol Pract Res 3(1):71-88. https://doi.org/10.1007/ s42532-021-00073-8

Xiang W-N (2021b) There is nothing as inspirational as a good example in the socio-ecological practice of nature-based solutions. A keynote speech at the 11th International Conference on Innovation in Urban and Regional Planning (INPUT 2020), September 8,2021 . The University of Catania, Italy (online presentation). http://www.input2020.unict.it/

Yang B (2019) Landscape performance: Ian McHarg's ecological planning in the Woodlands, Texas. Routledge, London and New York

Yang B, Li S (2016) Design with nature: Ian McHarg's ecological wisdom as actionable and practical knowledge. Landsc Urban Plan 155:21-32

Yang B, Li S (2019) Blending project goals and performance goals in ecological planning: Ian McHarg's contributions to landscape performance evaluation. Socio Ecol Pract Res 1(3-4):209-225. https://doi.org/10.1007/s42532-019-00029-z
Publisher's Note Springer Nature remains neutral with regard to jurisdictional claims in published maps and institutional affiliations.

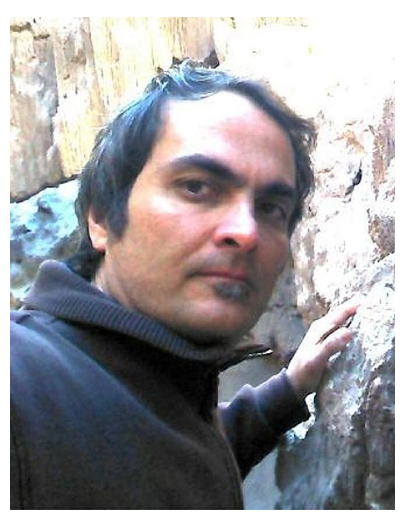

Daniele La Rosa is an associate professor of urban and environmental planning at the Department of Civil Engineering and Architecture, the University of Catania, Italy. His research topics include sustainable planning, ecosystem services, GIS applications for urban and landscape planning, environmental indicators, environmental strategic assessment, land use science and landscape studies.

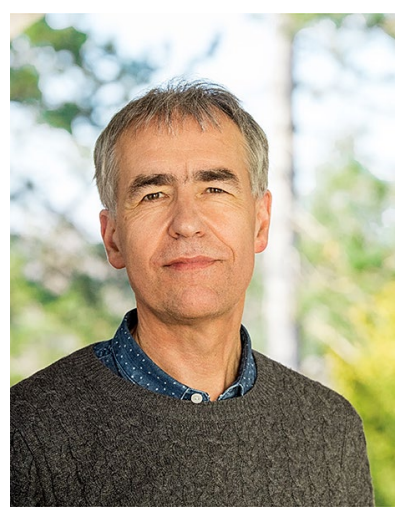

Stephan Pauleit is a professor and leads the Chair for Strategic Landscape Planning and Management at Munich Technical University, Germany, where he also directs the "Centre for Urban Ecology and Climate Change Adaptation". $\mathrm{He}$ is an expert in landscape planning and urban ecology and has developed a special interest in green infrastructure planning, nature-based solutions, adaptation strategies to climate change in the urban environment, and urban forestry.

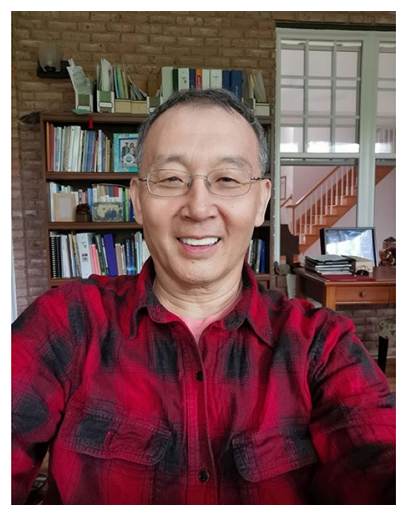

Wei-Ning Xiang is a professor of geography and earth sciences at the University of North Carolina at Charlotte, USA (1990-present). He has extensive international experience in education and research on urban and landscape planning. Having served as the co-editor in chief of Landscape and Urban Planning (2011-2018), he is the founding editor in chief of Socio-Ecological Practice Research (SEPR) (2019-present). 